\title{
Health education in the professional work of paramedics
}

\author{
Jarosław Piotr Chmielewski ${ }^{1, C-E \oplus}$, Tomasz Adam Karkowski ${ }^{2, C-D} \oplus$, Monika Szpringer ${ }^{3, C, E \oplus}$, \\ Magdalena Florek- Łuszczki ${ }^{4, E-F}{ }^{\oplus}$, Arkadiusz Rutkowski ${ }^{5, A-D \oplus}$ \\ ${ }^{1}$ College of Rehabilitation, Warsaw, Poland \\ ${ }^{2}$ Department of Labor and Social Policy, Faculty of Economics and Sociology, University of Łódź, Poland \\ ${ }^{3}$ Department of Medicine and Health Sciences, The Jan Kochanowski University in Kielce, Poland \\ ${ }^{4}$ Insitute of Rural Health in Lublin, Poland \\ ${ }^{5}$ Higher School of Social Sciences in Lublin, Poland \\ A - Koncepcja i projekt badania, B - Gromadzenie i/lub zestawianie danych, C - Analiza i interpretacja danych, \\ D - Napisanie artykułu, E - Krytyczne zrecenzowanie artykułu, F - Zatwierdzenie ostatecznej wersji artykułu
}

Chmielewski JP, Karkowski TA, Szpringer M, Florek- Łuszczki M, Rutkowski A. Health education in the professional work of paramedics. Med Og Nauk Zdr. 2019; 25(3): 131-134. doi: 10.26444/monz/111254

\begin{abstract}
In 1993, the World Health Organization (WHO) in its document „Health for All" stated that to improve public and professional competences in the field of health promotion and popularization of pro-health behaviours, broad health education in all aspects of the activities of society and the functioning of the entity is necessary. In the light of such goals, contemporary health education must focus on providing reliable knowledge and information on health. It must take into account all aspects of the economic activity of the State, as well as individual human behaviour affecting health. The role of medical personnel is crucial. The personnel, through their activities in the field of health education, can affect not only the increase in awareness, but also the change in social behaviour. The profession of a paramedic is usually associated with medical procedures; however, according to the current legal acts, a member of this professional group should also undertake educational activities to improve the health condition of patients. These activities are aimed at providing knowledge about health, increasing awareness of the benefits of health-related behaviours and taking control of health. Moreover, in the case of chronic diseases, properly conducted therapeutic communication can significantly alleviate the course of these diseases, slow down their progress and minimize the frequency of complications.
\end{abstract}

\section{Key words}

health education, paramedic, healthy behaviours, lifestyle

\section{INTRODUCTION}

The profession of a paramedic is usually associated with medical procedures in emergency situations. However, members of this professional group, due to their education and professional experience, are knowledgeable about public health and can undertake educational activities to improve the health of particular individuals and society.

With the implementation of one of the amendments of the National Medical Rescue Act in 2015 [1], health education and health promotion have been identified as being among the professional tasks performed by paramedics [2].

Contemporary health education should be directed, above all, towards creating habits about the protection and improvement of health, leading an appropriate lifestyle, encouraging interest in health-related issues and broadening knowledge about health needs [3]. Taking into consideration the fact that paramedical teams are normally dispatched to people with a particular health disorder, health education undertaken by paramedics is also an important part of therapeutic activities. These activities, while correctly carried out, may considerably alleviate the course of chronic diseases, slow down their progress and minimize the frequency of complications.

Address for correspondence: Jarosław Piotr Chmielewski, College of Rehabilitation Warsaw, Poland

E-mail: j.chmielewski@ios.gov.pl

Received: 3 June 2019; Accepted: 25 July 2019; First published: 05.09.2019
The educational potential of paramedics in health-related topics is shown by the fact that paramedical teams are dispatched very often, therefore reaching a wide range of potential audiences. According to Central Statistical Office, in 2016, paramedical units assisted almost 3.2 million people in Poland, two-thirds of the units being basic paramedical teams [4]. Taking into consideration the above-mentioned, it should be stressed that paramedics are the most numerous group among the personnel of emergency teams, and the tasks they perform are usually independent, unsupervised by medical doctor.

In the subject literature, many publications can be found on the health education tasks performed by medical doctors, nurses, nutritionists or counsellors; however, currently there is no interest in these activities being performed by paramedics. Therefore, the aim of this article is to draw attention to the possibility of performing health education tasks by paramedics working in emergency teams, and the influence such activities may have on improving the health condition of particular individuals and society.

Professional preparation of paramedics to undertake health education tasks. The sufficiently high - and at the same time specific nature of the task - level of professional competence of the paramedics should derive from their professional education, supplementary courses and personal initiatives to broaden their professional knowledge. The broad range of duties while working in an emergency team indicates that the 
paramedical profession is not only based on knowledge and skills in terms of medical procedures, but that it also requires a sufficiently high level of non-technical skills [5]. These skills allow the building of specific bonds with the patients, based on communication, health education and moral support.

Current syllabi of paramedicine degrees at undergraduate level include not only medical knowledge and skills on how to act while dealing with specific health disorders or emergencies, but also focus on personal and social competences, directed towards improving the health of individuals and society.

During their education, paramedics are taught the basic notions of how to improve the health condition of society during such subjects as health promotion, health education and public health. On the other hand, the knowledge and skills on how to identify the health needs of patients, as well as the rules of correct therapeutic communication, are acquired during classes on sociology, psychology, didactics, and the teaching methodology of first aid and qualified first aid $[6,7]$.

Graduate paramedics, having studied a range of specific subjects, should have appropriate social predispositions which, complemented with their specialised knowledge and skills of a paramedic, will allow them undertake activities aimed at the holistic improvement of the health of society. The effectiveness of health education undertaken by the paramedics lies above all in the awareness of the benefits of undertaking such activities.

Health education in paramedical teams and patients' health. In order to understand the influence of health education on the health condition of humans, first of all, the significance of the term 'health' should be explained. There is no unanimous definition of this term in the literature. For over 60 years the most popular and useful definition was coined in 1946 by the World Health Organization, which treats health in a holistic way. According to the WHO, 'health is a state of complete physical, mental and social well-being and not merely the absence of disease or infirmity' [8]. Health should be treated on multiple levels, and focused not only on the somatic area, the well-being of which not always guarantees completely correct mental and social conditions. Thus, health is a dynamic state and should be based only on positive aspects, as the presence of various factors can distort body homeostasis, causing intermediate states: relative health or relative disease [9]. They can be seen in terms of the capacity of a human being to function correctly and perform social roles, physical and mental potential that gives the opportunity to develop various activities, balance and harmony between specific areas of human life or in terms of well-being, content and self-fulfilment [10].

Bearing in mind Marc Lalonde's concept of 'half health' and indicating the lifestyle and health behaviour it describes as the factors determining health to the greatest extent (50$60 \%$ ) that a human can change to improve their health [11], it should be observed that health education can be treated as a tool of health promotion used to maintain or reinforce the health potential of society. Maintaining good health and reinforcing it requires mastering the skills that aim at taking care of the physical, mental and social areas. The adopted behaviour is related to different attitudes towards health, and can be positive (pro-health behaviour) or cause direct or indirect damage (anti-health behaviour) [10].

Currently, empowerment, based on increasing access to information on health and improving the capacity to use it correctly, is playing an important role. Human empowerment is understood as a relationship between a person and social reality. It is subjective and is related to the sense of identity, freedom, individuality and the hierarchy of principles [13]. The sense of empowerment is mostly dependent on others, especially relatives and healthcare professionals.

In times of an increasing demand for knowledge about health and searching for new ways to optimise education activities in this area, it is essential to include the discussed professional group in the medical personnel who are able to significantly influence the health and well-being of the population. This belief is also reflected in the subject literature $[14,15]$, according to which adding educational-therapeutic activities to the rescue duties in the professional role of paramedics results in a full application of the abilities of the paramedics, and an increase in the potential of pre-hospital healthcare. An increased scope of activities of the paramedics can significantly contribute to moulding the appropriate health abilities of the population, and reducing the existing health inequalities between the members of particular social groups, e.g. between rural and urban populations.

Thus, paramedics, being the biggest group of the emergency personnel, have the knowledge and skills in terms of activities aimed at improving the health condition of the population, and in their professional work they should undertake the contemporary premises of health education. All sorts of educational activities aimed at improving the health of patients and others present in a specific emergency (patients' relatives, caretakers, friends) are thought to increase the awareness of being empowered to take control over their health. Patients who broadens their knowledge about health related issues and acquire life skills will take over the responsibility for their own healthcare, improve the ability of 'self-managing' their health, minimize the prevalence of acute and chronic diseases, and will have the opportunity to choose a healthier life style and apply preventive medicine [16].

The activities carried out by paramedics during their work in the emergency teams focus, by fault, on a specific health disorder (organ or disorders of organs, diseases, physical injuries). Nevertheless, in the majority of cases, in spite of the pressure of time, contact with the patient leads to creating a specific bond based on communication. A relation with a person suffering from a particular health disorder frequently transforms into a therapeutic communication, that is all sorts of unspecified psychological activities accompanying the treatment. Their task is to reinforce medical activities with psychological resources that are integrated with them or other forms of healthcare [17]. According to research [18, 19], a large part of emergency teams dispatches do not have a direct relationship with health emergencies. It has been estimated that the percentage of the patients who were assisted but not taken to hospital was $22.9 \%$ in the case of top-urgency dispatches, and $29.8 \%$ in the case of lower-urgency dispatches [20]. Taking into consideration the above, it can be said that both the patients who were left at the emergency site, as well as those conveyed to hospital but not in a state of a direct danger to health (haemodynamically stable), require therapeutic communication. This kind of conversation with a patient (or their care taker) presents a wide range of possibilities for undertaking educational activities.

Calling an emergency unit is frequently caused by the patient's helplessness in the face of a specific disease. The 
best example are the elderly (late adult age) whose health condition is often downplayed due to progressing physical degenerative changes, and who stereotypically are assigned specific diseases. Such a situation contributes to their marginalisation and social withdrawal [21]. The lack of activities counteracting these phenomena deepen the somatic, mental and social dysfunction of this social group. A conversation and recommendations about how to proceed in the case of a specific disease, as well as information about the possibility to assist indicated health institutions (e.g. chronic pain unit) are the starting points for improving the heath of the elderly suffering from various types of diseases.

The need to undertake appropriate health education activities by paramedics while $t$ assisting patients are reflected in the situations when, e.g. the emergency units are dispatched in a short period of time to patients with specific diseases who, due to the lack of awareness, repeat the same mistakes (e.g. skipping medicine dose, diet mistakes). Repeating some health deteriorating behaviours can result in the lack of appropriate care of the patient, a distortion of their abilities of perception and attention (resulting from, e.g. dementia), as well as being the effect of helplessness and unclear communication between those patients and the healthcare personnel. Good communication skills of the emergency team allow the full participation of the patient in discussing their health. Patient-based communication allows the joint search for solutions to their health problems. As underlined by Arnold and Boggs [22], health success, being a result of therapeutic communication, consists of both words as well as interactions between the educator and the patient.

Health education during the work of emergency teams should be proactive and pre-therapeutic [23]. This means that the activities in this areas should be undertaken not only among the patients, but also as an across-the-board prophylaxis among healthy people. The activities of the paramedics are not only limited to the relation with the patient, but also concern those present at the site of an emergency who have contact with the patient on a daily basis, thus having a mutual influence in terms of lifestyle and health behaviours. The health education of people who comprise the social environment of the patient can contribute to them passing on the acquired knowledge to the patient and, which is important, to implementing it in the daily life, thereby increasing the probability of achieving the goals of the education process.

The benefits of health promotion and patients education by paramedics can contribute to increasing the social responsibility for health, disseminating correct health habits, improving the quality of life, and consequently diminishing the number of emergency medical calls resulting from unconscious behaviour. Appropriate competence will lead to making conscious health choices. Promoting patient-oriented healthcare and including the patient in the treatment and care will improve the perception of taking medication and the treatment regime [10].

Factors determining the effectiveness of health education in emergency units. Paramedics assisting in health emergencies in pre-hospital conditions are under the influence of various factors affecting the effectiveness of the undertaken actions.

One of the main factors that affects them is stress. This is caused by an unfavourable work environment linked to a constant contact with suffering, pain, trauma and death.
Another factor determining the quality and effectiveness of health education activities undertaken by the paramedics are the aggressive behaviours of patients or their environment. They are not always the result of fear or pain, but can also be the consequence of previous alcohol intake or other the abuse of other substances. Aggression can also be part of the course of diseases and mental disorders (psychosis, manic disorder, affective disorders) and somatic diseases (acute metabolic diseases) [24]. Regardless of its source, aggression that the paramedic experiences leads to lower job satisfaction, which in consequence can cause the burnout syndrome [25] that will have a destructive effect on their relationship with the patient.

Moreover, other stress factors while assisting an an emergency in pre-hospital conditions are: noise, work time (long, with shifts, not unified), physical exhaustion, the sense of not fulfilling the role, or inadequate remuneration on the level of professional responsibility [26].

\section{CONCLUSIONS}

To-date, health education undertaken by paramedics has not been the subject of a complex research and evaluation. From the perspective of public health, it seems necessary to undertake detailed research in this area, as the work of this professional group is based on constant contact with social health issues, what gives paramedics an opportunity to undertake remedial actions in terms of health.

In spite of various factors that limit the full and effective health education of emergency teams, paramedics are constantly communicating with the patients, their families and care takers, thanks to which they may pass on information to them. That information concerns, above all, disease prevention, actions to be taken when they occur, health prophylaxis, and the benefits of not pursuing anti-health behaviours.

The necessity to undertake actions that draw attention to the benefits of the possibility of improving health condition by way of health education undertaken by the paramedics should be stressed. In view of the contemporary notion of health promotion, the syllabi of degrees in paramedics should not only include medical procedures, but should also place greater emphasis on creating attitudes of undertaking independent actions related to increasing health education and awareness among patients.

\section{REFERENCES}

1. Act of 25th September 2015 on amending the National Medical Rescue Act, the Act on Medical Activity and the Amendment of the Act of Medical Activity and other acts (Dziennik Ustaw [Journal of Laws] of 2015, item 1887)

2. Act of 8 th September 2006 on National Medical Rescue (Dziennik Ustaw [Journal of Laws] of 2015, item 2195 as amended)

3. Mirowsky J, Ross C, E. Education, Social Status and Health, Transaction Publishers, New York 2017.

4. Central Statistical Office, Emergency medical aid and paramedicine in 2016 Information Note, https://stat.gov.pl, accessed 15.09.2018

5. Von Vyl T, Zuercher M., Amsler F, Walter B. Ummenhofer W. Technical and non-technical skills can be reliably assessed during paramedic simulation training. Acta Anaesthesiologica Scandinavica 2009; 53(1): $121-127$.

6. Jagiellonian University in Cracow, Information on the undergraduate syllabus of Paramedicine degree, https://www.usosweb. uj.edu.pl/kontroler.php?_action=actionx:katalog2/programy/pokazProgram(prg_ kod:WOZ-RM-0-ZD-6), acessed 4.09.2018. 
7. National Vocational University in Nysa, Term/annual diagrams of the syllabus - Paramedicine, https://www.pwsz.nysa.pl/dwm/index.php?l $=1 \&$ id_j=14\&id_p=/katalog.php, accessed 4.09.2018.

8. Constitution of the World Health Organization, Agreement singed by the governments on the International Health Conference and the Protocol on the International Public Hygiene Office, signed in New York on 22 July 1946, (Dziennik Ustaw [Journal of Laws] of 1948, item 477)

9. Ostrzyżek A, Marcinkowski JT. Biomedyczny versus holistyczny model zdrowia a teoria i praktyka kliniczna. Probl Hig Epidemiol. 2012; 93(4): 682-686.

10. Woynarowska B. Edukacja zdrowotna. Podstawy teoretyczne, Metodyka, Praktyka. Warszawa 2017.

11. Gaweł A. Współczesna koncepcja zdrowia - odniesienia edukacyjne, w: Skulicz D. (red.), Zdrowie w edukacji elementarnej, Kraków 2004.

12. Sarbinowska J, Jędrzejek M, Synowiec-Piłat M. Idea upodmiotowienia na rzecz zdrowia na przykładzie wybranych europejskich kampanii społecznych. Hygeia Public Health. 2013; 48(4): 424-431.

13. de Walden-Gałuszko K. Possibilities of quality of life improvement in patients with advanced disease. Med Paliatywna Praktyce 2017; 11(2): 74-77.

14. O’Meara P, Walker J, Stirling C, Pedler D, Tourle V. i in. The rural and remote ambulance paramedic: moving beyond emergency response, NSW: School of Public Health, Charles Sturt University, Bathurst 2006.

15. Mulholland P, Barnett T, Spencer J. Interprofessional learning and rural paramedic care. Rural and Remote Health 2014; 14(3): 2821.

16. Dreeben O. Patient Education in Rehabilitation, Jones and Bartlett Publishers, Sudbury 2010.

17. Motyka M. Znaczenie komunikacji terapeutycznej z pacjentem. Sztuka leczenia 2013; (3-4): 17-24.
18. Aftyka A, Rudnicka-Drożak E. Nieuzasadnione wezwania Zespołów Ratownictwa Medycznego w materiale Wojewódzkiego Pogotowia Ratunkowego SP ZOZ w Lublinie. Anestezjologia i Ratownictwo 2014; 7(4): 152-159.

19. Kamecki A. Wyjazdy nieuzasadnione w systemie Państwowego Ratownictwa Medycznego - konieczność czy zagrożenie? Edukacja dla Bezpieczeństwa. Przeglad Naukowo-Metodyczny 2017; 3(36): 205-219.

20. Guła P, Wejnarski A, Moryto R, Gałązkowski R, Karwan K, Świeżewski S. Analiza działań zespołów ratownictwa medycznego w polskim systemie Państwowego Ratownictwa Medycznego. Czy model podziału na zespoły specjalistyczne i podstawowe znajduje uzasadnienie? Wiad Lek. 2014; 67(4): 469-475.

21. Dzięgielewska M. Edukacja osób starszych w codzienności, w: Kuchcińska M. (red.), Edukacja do i w starości, Bydgoszcz 2008.

22. Arnold E, Boggs K. Interpersonal relationship. Professional communication skills for nurses, Elsevier Saunders, Missouri 2016.

23. Lizak D, Goździalska A, Seń M, Jaśkiewicz J, Satora R. Promocja zdrowia i edukacja zdrowotna - obowiązek czy wyzwanie dla pracowników ochrony zdrowia XXI w.? W: Działania opiekuńcze w profilaktyce i terapii. Goździalska A, Jaśkiewicz J, Dębska G. (red.), Oficyna Wydawnicza AFM, Kraków 2014: 35-44.

24. Barziej I, Hasij J, Orłowska W, Rydzek J, Letka E. Postepowanie z pacjentem pobudzonym i agresywnym. Na Ratunek 2010; 2/2010: 42-45.

25.ZZurowska-Wolak M, Wolak B, Mikos M, Juszczyk G, Czerw A. Stres i wypalenie zawodowe w pracy ratowników medycznych. J Education Health Sport. 2015; 5(7): 43-50.

26. Rutkowski A, Stankiewicz S. Zjawisko stresu zawodowego w pracy ratownika medycznego. W: Chmielewski J, Czarny-Działak M, Pawlas N. (red), Ochrona zdrowia pracujących, Warszawa 2017.

\title{
Edukacja zdrowotna w pracy zawodowej ratowników medycznych
}

\begin{abstract}
IStreszczenie
Światowa Organizacja Zdrowia (WHO) w dokumencie "Zdrowie dla wszystkich" z 1993 roku stwierdziła, że w celu poprawy publicznych i zawodowych kompetencji w zakresie promocji zdrowia i popularyzacji zachowań prozdrowotnych niezbędna jest szeroka edukacja zdrowotna we wszystkich aspektach działalności społeczeństwa, jak i funkcjonowania jednostki. W świetle tak sformułowanych celów współczesna edukacja zdrowotna powinna być ukierunkowana na dostarczaniu rzetelnej wiedzy i informacji na temat zdrowia. Musi ona uwzglęniać wszystkie aspekty działalności gospodarczej państwa, jak i indywidualnych zachowań człowieka mających wpływ na stan zdrowia.

Znacząca jest tu rola personelu medycznego, który poprzez swoje działania w obszarze edukacji zdrowotnej może wpływać nie tylko na wzrost świadomości, ale i zmianę zachowań społecznych.

Zawód ratownika medycznego kojarzony jest niemal wyłącznie z wykonywaniem procedur medycznych, jednak w świetle obecnie obowiązujących przepisów prawa członkowie tej grupy zawodowej powinni również podejmować czynności o charakterze edukacyjnym na rzecz poprawy stanu zdrowia pacjentów. Realizacja tego typu działań ma na celu przekazanie wiedzy na temat zdrowia, zwiększenie świadomości w zakresie korzyści wynikających z podejmowania zachowań prozdrowotnych oraz przejęcie kontroli nad zdrowiem. Natomiast w przypadku chorób przewlekłych prawidłowo prowadzona komunikacja terapeutyczna może w znacznym stopniu złagodzić przebieg tych chorób, spowalniać ich postęp i minimalizować częstość powikłań.
\end{abstract}

\section{Słowa kluczowe}

edukacja zdrowotna, ratownik medyczny, zachowania prozdrowotne, styl życia 